\title{
Correction to: How to Measure Retirement Age? A Comparison of Survey and Register Data
}

\section{Harpa S. Eyjólfsdóttir ${ }^{1} \cdot$ Isabel Baumann ${ }^{2,3} \cdot$ Neda Agahi $^{1}$ (D) Carin Lennartsson ${ }^{1}$}

Published online: 6 February 2020

(C) Springer Nature B.V. 2020

\section{Correction to: Journal of Population Ageing https://doi.org/10.1007/s12062-019-09254-6}

The references to Kridahl (2017) and Kridahl \& Silverstein (2017) should be disregarded in Table 1 on page 7; on page 4, line 36-37; on page 8, line 4; and on page 10, line 14-15. Likewise, they should be disregarded from the list of references.

Publisher's Note Springer Nature remains neutral with regard to jurisdictional claims in published maps and institutional affiliations.

The online version of the original article can be found at https://doi.org/10.1007/s12062-019-09254-6

Harpa S. Eyjólfsdóttir

harpa.eyjolfsdottir@ki.se

Isabel Baumann

isabel.baumann@zhaw.ch

Neda Agahi

neda.agahi@ki.se

Carin Lennartsson

carin.lennartsson@ki.se

1 Aging Research Center, Karolinska Institutet and Stockholm University, Tomtebodavägen 18 A, 17165 Solna, Sweden

2 Center for Health Sciences, Zurich University of Applied Sciences, Technikumstrasse 81, 8400 Winterthur, Switzerland

3 National Center of Competence in Research "Overcoming Vulnerability: Life Course

Perspectives", Geneva, Switzerland 